\title{
COMMUNITY ONSITE ANAEROBIC SEWAGE TREATMENT IN A UASB-SEPTIC TANK SYSTEM: SYSTEM BEHAVIOUR DURING WINTER PERIOD IN PALESTINE
}

\author{
Wafa Al-Jamal \\ Nidal Mahmoud \\ Birzeit University, Palestine
}

\begin{abstract}
The effect of the Mediterranean climate low temperature period on the performance UASBseptic tank treating concentrated domestic sewage $(\mathrm{COD} \sim 100 \mathrm{mg} / \mathrm{L})$ in Palestine was studied. Two community onsite UASB-Septic tank reactors (capacity: $0.8 \mathrm{~m}^{3}$, height: $2.5 \mathrm{~m}$ ) were operated in parallel over a year and monitored over the colder half of the year. The reactors were operated under two different HRT ( 2 days for R 1 and 4 days for R2) at average sewage temperature of $17.3{ }^{\circ} \mathrm{C}$ with 12 and $25{ }^{\circ} \mathrm{C}$ extreme values. The $\mathrm{COD}_{\mathrm{ss}}$ in the raw sewage represented a high fraction of the total COD, viz. about $43.7 \%$ from the $\mathrm{COD}_{\text {tot }}$. $\mathrm{R} 1$ achieved mean removal efficiencies for $\mathrm{COD}_{\text {tot }}, \mathrm{COD}_{\text {sus }}, \mathrm{COD}_{\text {col }}, \mathrm{COD}_{\mathrm{dis}}$, of $51 \%, 83 \%, 20 \%$ and $24 \%$ respectively and $\mathrm{BOD}_{5}$ and TSS average removal efficiencies of $45 \%$ and $74 \%$ respectively. R2 achieved mean removal efficiencies for $\mathrm{COD}_{\text {tot }}, \mathrm{COD}_{\text {sus }}, \mathrm{COD}_{\text {col }}, \mathrm{COD}_{\mathrm{dis}}$, of $54 \%, 87 \%, 10 \%$ and $28 \%$, respectively with $\mathrm{BOD}_{5}$ and TSS average removal efficiency of $49 \%$ and $78 \%$ respectively. The sludge production from both reactors was very low with $\mathrm{VS} / \mathrm{TS}$ ratios of 67.9 and 67.02 of the sludges in $\mathrm{R} 1$ and $\mathrm{R} 2$, respectively. Based on the removal efficiencies and sludge production it can be concluded that the here researched UASB-Septic tank system is a potential compact and effective community onsite pretreatment unit for domestic wastewater in Palestine. The reactor can be designed at either 2 or 4 days HRT, but slight preference might be given to 4 days HRT when sludge production is of concern.
\end{abstract}

\section{KEYWORDS}

Anaerobic wastewater treatment; on-site; domestic sewage; UASB-Septic tank

\section{INTRODUCTION}

Wastewater management is a sector, which globally requires more attention. Today sewage is the largest pollutant on a global scale, as particularly in developing countries, only a small fraction of the sewage produced is treated. For example, In Palestine about $73 \%$ of the West Bank households have cesspit sanitation and almost 3\% are left without any sanitation system. The cesspits are left without lining, so sewage infiltrates into the earth layers and eventually to groundwater. Consequently, cesspits themselves pose increasing environmental pollution problems. The local Palestinian experience with constructing centralized aerobic activated sludge plants is not encouraging due to the incapability of people to afford the operational and capital costs. Even for wealthy countries, the connection of dispersed human settlements like remote houses, summer houses, farms and recreation facilities to sewerage system is too 
costly. For instance, in Finland wastewater from rural areas $(20 \%$ of the population) is a concern due to water sources pollution, and in the United States more than 20 million homes ( $20 \%$ of the population), are served with onsite wastewater treatment facilities of mainly septic tanks. Accordingly, decentralised wastewater management is inevitable for comprehensive wastewater treatment and environmental protection world wide.

The septic tank is the most known and commonly applied system for on-site anaerobic pretreatment of sewage. However, the performance of the septic tanks is rather poor despite the long operated hydraulic retention time (HRT) due to their inherent design feature, viz. the horizontal flow mode of the influent sewage. A significant improvement of the septic tank was achieved by applying upward flow and gas/solids/liquid separation device at the top, which resulted in the so called UASB-septic tank system [1]. The reactor is operated in an upflow mode as a UASB reactor resulting in both improved physical removal of suspended solids and improved biological conversion of dissolved components, and sludge gradually accumulates and stabilises in the reactor, as in a septic tank (Zeeman et al., 2000).

Studies with UASB-Septic tanks treating domestic sewage are scarce, and to our knowledge so far only a one research project had been conducted on the use of a UASB-septic tank system for the onsite sewage treatment at Dutch and Indonesian ambient conditions by Lettinga and his co-workers [1,2](Bogte et al., 1993; Lettinga et al., 1993). Nonetheless, the system has not been applied in other countries of different environments and sewage characteristics nor it has been optimised. For instance, in Palestine and Jordan in the Middle East, sewage is characterised with high COD concentrations exceeding sometimes $1500 \mathrm{mg} / \mathrm{L}$ with high fraction of CODss (up to $70-80 \%$ ) [3, 4].. In addition, in the Middle East region, the ambient temperature fluctuates over the year coupled with sewage temperature fluctuation in the range 15 and $25{ }^{\circ} \mathrm{C}$, during winter and summer times respectively. Previous research has demonstrated that the performance of single stage UASB systems at low temperatures (5$20^{\circ} \mathrm{C}$ ) is severely limited by the slow hydrolysis of entrapped solids that accumulate in the sludge bed [5]. This phenomenon is of particular concern when the reactor is fed with highly concentrated raw sewage at low temperatures. The use of the UASB system for the treatment of sewage with relatively high COD concentration is still undergoing trials and argued that such knowledge is important to improve the reliability of anaerobic processes. This is because knowledge of the performance of anaerobic reactors treating municipal wastewater in extreme situation is limited.

The main objectives of this research were to asses the process performance of the community onsite UASB-septic tank for the treatment of concentrated domestic sewage under rather low temperature conditions and also to increase the knowledge on the system design. In view of that, two UASB-septic tank reactors treating domestic sewage in Palestine had been operated under ambient conditions at HRTs of two and four days. The reactors were operated for a year and monitored for the last six months which are the cold period of the year.

\section{MATERIALS AND METHODS}

\subsection{Experimental set-up.}

Two UASB-septic tank reactors, namely $\mathrm{R} 1$ and $\mathrm{R} 2$, were installed in parallel at the centralised sewage treatment plant of Al-Bireh City/ Palestine. The reactors were made of galvanized steel with working volumes of $0.8 \mathrm{~m}^{3}$ (height $2.50 \mathrm{~m}$; diameter $0.638 \mathrm{~m}$ ). Nine sampling ports were installed along the reactor height at $0.25 \mathrm{~m}$ for sludge sampling, with the first port at $0.15 \mathrm{~m}$ from the bottom of the reactors. The influent was distributed in the reactor 
through Polyvinyl Chloride (PVC) tube with 4 outlets located $5 \mathrm{~cm}$ from the bottom. Biogas was passed through a $16 \% \mathrm{NaOH}$ solution for $\mathrm{CO}_{2}$ scrubbing, and then methane quantity was continuously measured by wet gas meters. Schematic diagram of the experimental set-up is presented in Figure 1 .

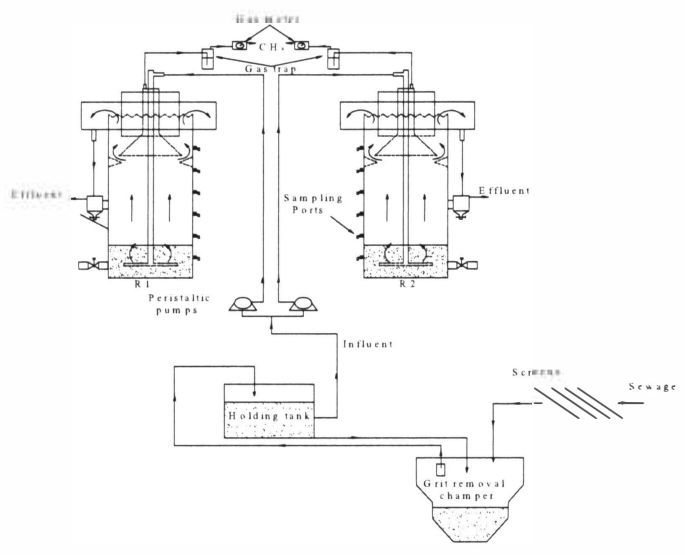

Figure 1. Schematic diagram of the experimental set-up (not to scale)

\subsection{Pilot plants start-up, operation and monitoring.}

The UASB-septic tank reactors were started up during spring, ca. April. The reactors were operated in parallel and continuously at ambient environmental conditions for a whole year. The reactors were fed with domestic sewage pre-treated with screens and grit removal chamber. The sewage was pumped every five minutes to a holding tank $(200 \mathrm{~L}$ plastic container), with a resident time of about 5 minutes, where the reactors were fed and the influent was sampled. The reactors were inoculated with anaerobic sludge obtained from a household cesspit (R1 and R2 respectively with 10 and $20 \%$ of the reactors volume), and operated in parallel at ambient temperature. Grab samples of raw sewage and reactors effluents were collected and analysed two to three times a week after six moths of staring up the reactors, viz. starting in October. Samples were stored at $4{ }^{\circ} \mathrm{C}$ till being analysed. Daily monitoring included wastewater and ambient temperature and biogas production measurements. The atmospheric pressure was measured in situ.

\subsection{Analytical Methods}

Total suspended solids (TSS), volatile suspended solids (VSS), total solids (TS), volatile solids (VS), ammonium $\left(\mathrm{NH}_{4}{ }^{+}\right)$, kjeldahl-nitrogen $(\mathrm{Kj}-\mathrm{N})$, Chemical Oxygen Demand (COD), Biological Oxygen Demand (BOD), total $\mathrm{PO}_{4}-\mathrm{P}$, dissolved $\mathrm{PO}_{4}{ }^{3-}-\mathrm{P}$, and $\mathrm{SO}_{4}{ }^{2-}$ were measured according to standard methods [6]. Raw samples were used for measuring total COD (CODt), $4.4 \mu \mathrm{m}$ folded paper-filtered (Schleicher and Schuell 5951/2, Germany) samples for paper filtered COD (CODp) and $0.45 \mu \mathrm{m}$ membrane - filtered (Schleicher and Schuell ME 25, Germany) samples for dissolved COD (CODdis). The suspended COD (CODss) and colloidal COD (CODcol) were calculated as the difference between CODt and CODp and the difference between CODp and CODdis, respectively. The volatile fatty acids (VFA) analysis 
was carried out as described by (Buchauer, 1998). $\mathrm{pH}$ was measured using EC $\mathrm{pH}$ meter $(\mathrm{HACH})$. All samples were analysed in duplicate except, VFA and SVI in single.

Biodegradability of the effluent COD and sludge stability of both reactors were measured twice in duplicate using $500 \mathrm{~mL}$ working volume batch reactors incubated at $30{ }^{\circ} \mathrm{C}$ for a period of 120 days as described by [3].

\subsection{Calculations}

\section{Nomenclature}

$\mathrm{COD}_{\text {tot }}$ : amount of total COD in the tested sample $(\mathrm{mg} \mathrm{COD} / \mathrm{l})$

$\mathrm{COD}_{\text {tot, inf }}$ and $\mathrm{COD}_{\text {tot, eff: }}$ amount of total COD in influent and effluent (mg COD/l)

$\mathrm{COD}_{\text {dis, inf }}$ and $\mathrm{COD}_{\text {dis, eff: }}$ amount of dissolved COD in influent and effluent (mg COD/l)

$\mathrm{COD}_{\mathrm{VFA} \text {, inf }}$ and COD $\mathrm{VFA}$. eff: amount of VFA in influent and effluent (mg VFA as COD/l)

$\mathrm{COD}_{\mathrm{CH} 4}$ : amount of produced $\mathrm{CH}_{4}$ (liquid form + gas form) $\left(\mathrm{mg} \mathrm{CH} \mathrm{CH}_{4}\right.$ as $\left.\mathrm{COD} / \mathrm{l}\right) ; \mathrm{CH}_{4}$ (liquid form) was calculated according to Henry's law assuming $70 \%$ of the biogas is $\mathrm{CH}_{4}$

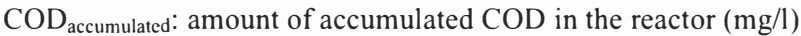

\section{Biodegradability and Stability}

Biodegradability $(\%) \mathrm{F}=100\left(\mathrm{COD}_{\mathrm{CH} 4} / \mathrm{COD}_{\text {tot. } \mathrm{t}=0 \text { days }}\right)$

(1)

\section{Hvdrolysis ${ }_{2}$ Acidification and Methanogenesis}

Percentage of hydrolysis (H), acidification (A) and methanogenesis (M) were calculated according to equations 2,3 and 4 , respectively.

$$
\begin{aligned}
& \mathrm{H}(\%)=100\left(\frac{\mathrm{COD}_{\mathrm{H}_{4}}+\mathrm{COD}_{\text {dis. }} \text { ff }-\mathrm{COD}_{\text {dis. inf }}}{\mathrm{COD}_{\text {tot, }} \text { inf }-\mathrm{COD}_{\text {dis. inf }}}\right)
\end{aligned}
$$

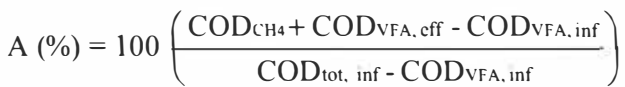

$$
\begin{aligned}
& \mathrm{M}(\%)=100\left(\frac{\mathrm{CODaH}_{4}}{\mathrm{COD}_{\text {tot. inf }}}\right)
\end{aligned}
$$

\section{COD - mass balance}

\subsection{Statistical data analysis}

Statistical comparisons of means was followed by "Paired samples t-test" for the measured parameters of the two reactors using the SPSS program for windows- Release 11.0.0, SPSS ${ }^{\circledR}$ Inc. (2001), with $p$ value $<0.05$ considered significantly different. 


\section{RESULTS AND DISCUSSION}

\subsection{Influent specifications}

The influent average $C O D_{t o t}, C O D_{s s}, C O D_{d i s}$ and the $C_{\text {col }}$ were $905(253.5) \mathrm{mg} / \mathrm{l}$, $396(163.8) \mathrm{mg} / \mathrm{l}$ and $350(124.2) \mathrm{mg} / \mathrm{l}$ and 135(42.2) $\mathrm{mg} / \mathrm{l}$, respectively. The $\mathrm{COD}_{\mathrm{ss}}$ represented a high fraction of the $\mathrm{COD}_{\text {tot }}$ of $43.7 \%$ which is less than the value reported by [9]Mahmoud et al. (2003) of 58\%. The percentages of the other fraction of the $\mathrm{COD}_{\text {tot }}$ were $14.9 \%$ and $38.6 \%$ for $\mathrm{COD}_{\text {col }}$ and $\mathrm{COD}_{\text {dis, }}$, respectively. The average VFA of wastewater entered to the treatment plant was about $99(55.8) \mathrm{mg} \mathrm{COD} / \mathrm{l}$ as an average value, which is less that the value reported by [9]Mahmoud et al. (2003) of $150 \mathrm{mg} \mathrm{COD/l}$. The ratios between the acidified (VFA/COD tot $)$, the hydrolysed percentage $\left(\mathrm{COD}_{\mathrm{dis}} / \mathrm{COD}_{\mathrm{tot}}\right)$, the VFA part of the dissolved COD (VFA/COD $\left.\mathrm{dis}_{\mathrm{s}}\right)$ and the (VSS/TSS) and $\left(\mathrm{COD}_{\mathrm{ss}} / \mathrm{VSS}\right)$ are presented in Table 2 and compared with other studies in Jordan and Palestine.

Table 2. Percentage of hydrolysis and acidification of total COD and acidification of dissolved COD and VSS/TSS and COD sus $/$ VSS ratios for the influent of Al-Bireh WWTP/Palestine and Abu-Nusier WWTP/Jordan

\begin{tabular}{lccccc}
\hline & $\left(\mathrm{VFA} / \mathrm{COD}_{\mathrm{tot}}\right)$ & $\left(\mathrm{VFA} / \mathrm{COD}_{\mathrm{dis}}\right)$ & $\left(\mathrm{COD}_{\mathrm{dis}} / \mathrm{COD}_{\mathrm{tot}}\right)$ & $(\mathrm{VSS} / \mathrm{TSS})$ & $\left(\mathrm{COD}_{\text {sus }} / \mathrm{VSS}\right)$ \\
\hline Palestine $^{(1)}$ & 10 & 36 & 28 & 84 & 1.49 \\
Palestine $^{(2)}$ & 10.9 & 28.28 & 38.7 & 84.4 & 1.27 \\
Jordan $^{(3)}$ & 9.4 & 40 & 23.5 & 72 & 3.21 \\
\hline
\end{tabular}

Palestine studies of Al Bireh City sewage/Palestine:(1) Mahmoud et al. (2003); (2) this research); Abu-Nuseir sewage/ Jordan: (3) Halalsheh (2002)

The average TSS and VSS concentrations of the influent were 371(141) mg/l and 313(128) $\mathrm{mg} / \mathrm{l}$, respectively. The (VSS/TSS) ratio was $84.4 \%$. During the period of the study, the sewage temperature fluctuated between 12 and $25^{\circ} \mathrm{C}$ with average value of $17.34^{\circ} \mathrm{C}$.

\subsection{Performance of the two UASB-septic tank reactors}

The UASB-septic tank reactor that was operated at 2 days HRT achieved average removal efficiencies of $\mathrm{COD}_{\text {tot }}, \mathrm{COD}_{\text {sus }}, \mathrm{COD}_{\text {col }}$ and $\mathrm{COD}_{\text {dis }}$ of respectively $51 \%(9), 83 \%(10)$, $20 \%(32), 24 \%(15)$, and the other reactor with 4 days HRT achieved values of respectively $54 \%$ (11), $87 \%$ (8), 10\% (37), 28\% (18). Apparently R2 was more efficient in removing all COD fractions except the colloidal part. However, the statistical analysis revealed that the difference in the removal efficiencies was only significant for $C O D_{\text {sus }}(\rho<0.05)($ Table 3$)$. The influent and effluent $\mathrm{COD}_{\text {tot }}$ concentration of $\mathrm{R} 1$ and $\mathrm{R} 2$ and the achieved removal efficiencies are presented in Figure 2. 
Kalmar ECO-TECH '07

KALMAR, SWEDEN, November 26-28, 2007
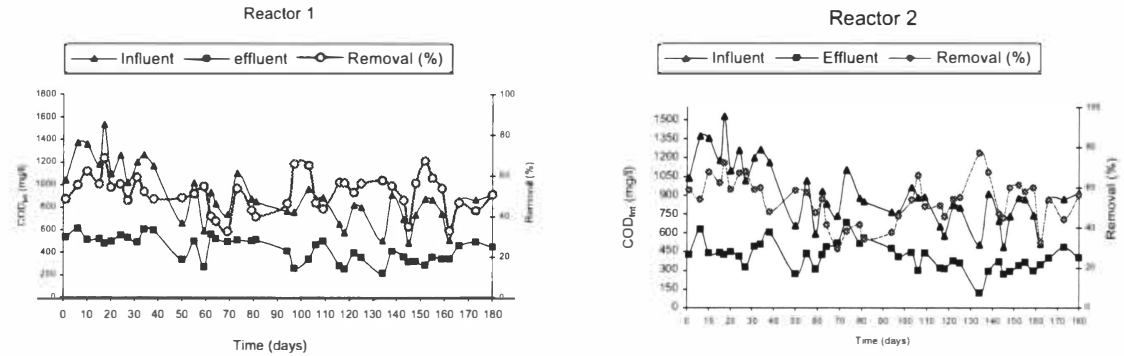

Figure 2. $C O D_{10 t}$ influent and effluent concentrations and removal efficiencies for RI (left) and $R 2$ (right). 
Table 3. Research results for the effluent concentration and removal efficiency (\%) during the whole period of experiment in the two UASBseptic tank reactors under the imposed operational conditions. Standard deviations are presented between brackets.

\begin{tabular}{|c|c|c|c|c|c|c|c|c|c|c|}
\hline \multirow{3}{*}{ Parameter } & \multirow{3}{*}{ Sample \# } & \multirow{3}{*}{$\begin{array}{l}\text { Influent } \\
\text { concentration }\end{array}$} & \multicolumn{4}{|c|}{$\begin{array}{c}\text { UASB-septic tank (R1) } \\
(\text { HRT = } 2 \text { days) }\end{array}$} & \multicolumn{4}{|c|}{$\begin{array}{l}\text { UASB-septic tank (R2) } \\
\quad(\text { HRT }=4 \text { days) }\end{array}$} \\
\hline & & & \multicolumn{2}{|c|}{ Effluent concentration } & \multicolumn{2}{|c|}{ Removal efficiency (\%) } & \multicolumn{2}{|c|}{ Effluent concentration } & \multicolumn{2}{|c|}{ Removal efficiency (\%) } \\
\hline & & & Range & Average & Range & Average & Range & Average & Range & Average \\
\hline $\mathrm{COD}_{\mathrm{tot}}$ & 41 & $905(254)$ & $611-213$ & $433(109)$ & $69-32$ & $51(9)$ & $680-115$ & $408(109)$ & $77-29$ & $54(11)$ \\
\hline $\mathrm{COD}_{\mathrm{ss}}$ & 41 & $396(164)$ & $142-5$ & $62(34)$ & $99-58$ & $83(10)$ & $151-8$ & $45(30)$ & $97-66$ & $87(8)$ \\
\hline $\mathrm{COD}_{\mathrm{col}}$ & 41 & $135(43)$ & $215-9$ & $104(46)$ & $96--38$ & $20(32)$ & $183-9$ & $112(41)$ & $92-36)$ & $10(37)$ \\
\hline $\mathrm{COD}_{\mathrm{dis}}$ & 41 & $350(124)$ & $504-62$ & $265(96)$ & $56-6$ & $24(15)$ & $481-66$ & $248(94)$ & $58--34$ & $28(18)$ \\
\hline VFA as COD & 41 & $99(56)$ & $178-10$ & $80(37)$ & $76-\cdot 135$ & $-1(52)$ & $186-4$ & $69(38)$ & $(89-238$ & $2(82)$ \\
\hline $\mathrm{BOD}_{5}$ & 13 & $502(133)$ & $132-410$ & $283(81)$ & $60-25$ & $43(12)$ & $331-133$ & $246(64)$ & $65-15$ & $49(16)$ \\
\hline $\mathrm{NKj}$ as $\mathrm{N}$ & 14 & $70(10.31)$ & $(77-45)$ & $58(7.5)$ & $29-5.2$ & $17(7.2)$ & $74-45$ & $59(8.4)$ & $33-4.6$ & $15(8.3)$ \\
\hline $\mathrm{NH}_{4}{ }^{-}$as $\mathrm{N}$ & 19 & $39.2(18)$ & $(75.5-7.2)$ & $35.6(20.7)$ & $60.7-20.2$ & $\begin{array}{l}11.5(20 . \\
7)\end{array}$ & $72.23-3.7$ & $36(21.2)$ & $59.44--14.2$ & $13.1(22.6)$ \\
\hline Total $\mathrm{PO}_{4}$ as $\mathrm{P}$ & 11 & $10.1(3.5)$ & $(13.4-4.2)$ & $9.8(3)$ & $24.3--45.2$ & $\begin{array}{l}0.43(16 . \\
6)\end{array}$ & $14-4.7$ & $10.25(3.1)$ & $24-42.7$ & $-4.34(16.4)$ \\
\hline $\mathrm{PO}_{4}^{-3}$ as $\mathrm{P}$ & 11 & $8.4(4.1)$ & $(16.7-3.6)$ & $10.7(4.47)$ & $-2.6-194.5$ & $\begin{array}{l}37.8(53 . \\
5)\end{array}$ & $18.3-4.4$ & $11.9(4.5)$ & $-7.8-193.1$ & $-57.3(59)$ \\
\hline $\mathrm{SO}_{4}^{-2}$ & 15 & $94.7(24)$ & $(49.4-20.9)$ & $38.4(8.23)$ & $76.32-44.68$ & $\begin{array}{c}57.65(8 . \\
48)\end{array}$ & $54.67-18.47$ & $36.47(10.74)$ & $74.73-51.84$ & $61.45(6.16)$ \\
\hline TSS & 13 & $371(141)$ & $(130-50)$ & $89(29)$ & $87-50$ & $74(10)$ & $119-20$ & $73(32)$ & $95-52$ & $78(11)$ \\
\hline VSS & 13 & $313(128)$ & $(109-40)$ & $75(26)$ & $89-49$ & $74(10)$ & $102-16$ & $59(27)$ & $95-48$ & $78(12)$ \\
\hline (VSS/TSS) & 13 & $83(4)$ & $(97-73)$ & $84(6)$ & $\ldots$ & $\ldots$ & $86-72$ & $81(4)$ & -. & -. \\
\hline $\mathrm{pH}$ & 39 & $7.6(0.28)$ & $7.68-7.14$ & $7.44(0.13)$ & - & - & $7.79-7.1$ & $7.47(0.16)$ & - & - \\
\hline${ }^{*}$ Biodegradability & 2 & ... & $(59.4-37.3)$ & $47.64(9.6)$ & $\ldots$ & $\ldots$ & $51.9-34.4$ & $41.7(7.5)$ & ... & -.. \\
\hline
\end{tabular}

All parameters are in mg/l except: $\mathrm{pH}$ no units; VSS/TSS (\%) ; Biodegradability (\%). ${ }^{*}$ Biodegradability was examined twice at day 204 and day 250 from the start up of the reactors 
Both reactors achieved high average removal efficiencies of $\mathrm{COD}_{\text {sus }}$ of $83 \%(10)$ and $87 \%$ (8) in R1 and R2, respectively with average effluent concentration of $\mathrm{COD}_{\text {sus }} 62$ (34) $\mathrm{mg} / \mathrm{l}$ and 45 (30) $\mathrm{mg} / \mathrm{l}$ for R 1 and R2, respectively during the cold period of the year. The results presented in Figure 3 clearly show that the effluent concentrations of $\mathrm{COD}_{\mathrm{ss}}$ of both reactors were very stable. $R 2$ achieved significantly $(\mathrm{p}<0.05)$ better $\mathrm{COD}_{\text {sus }}$ removal efficiency than R1.
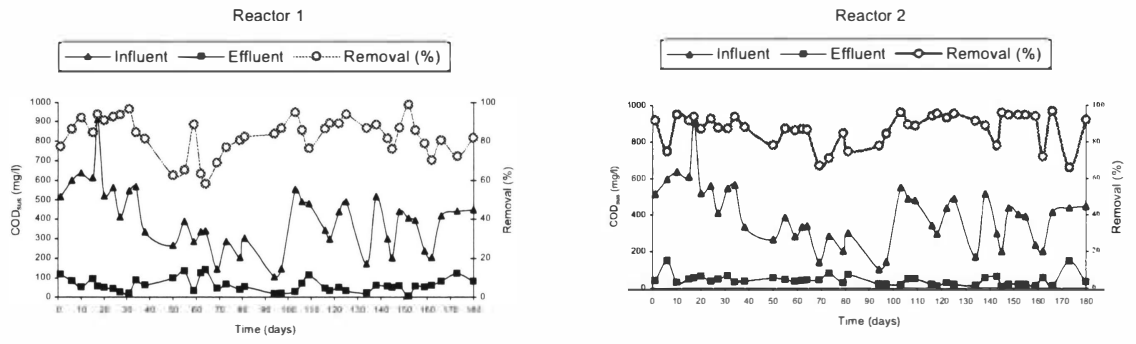

Figure 3. $C O D_{\text {sus }}$ influent and effluent concentrations and removal efficiencies for RI (left) and $R 2$ (right)

During the cold period of the year both reactors R1 and R2 were not sufficient for removing $\mathrm{COD}_{\text {col }}$ from the influent. The average removal efficiencies were $20 \%(32)$ and $10 \%$ (37) for $\mathrm{R} 1$ and $\mathrm{R} 2$, respectively with insignificant $(\mathrm{p}>0.05)$ difference between both reactors. In addition to the low removal rate of $\mathrm{COD}_{\mathrm{col}}$, even negative removal efficiency had been observed, where this means that the effluent concentration of $\mathrm{COD}_{\mathrm{col}}$ some times exceeds the influent concentration. The same results had also been observed by [7], in which is justified as the increase in the $\mathrm{COD}_{\text {col }}$ was generated from the $\mathrm{COD}_{\text {sus }}$ that had been digested. The average $\mathrm{COD}_{\mathrm{di}}$ removal rates were $24 \%$ (15) and $28 \%$ (18) for R 1 and $\mathrm{R} 2$, respectively (see "Table 3" and "Figure 4") with no significant difference between the two reactors ( $\mathrm{p}>0.05)$.
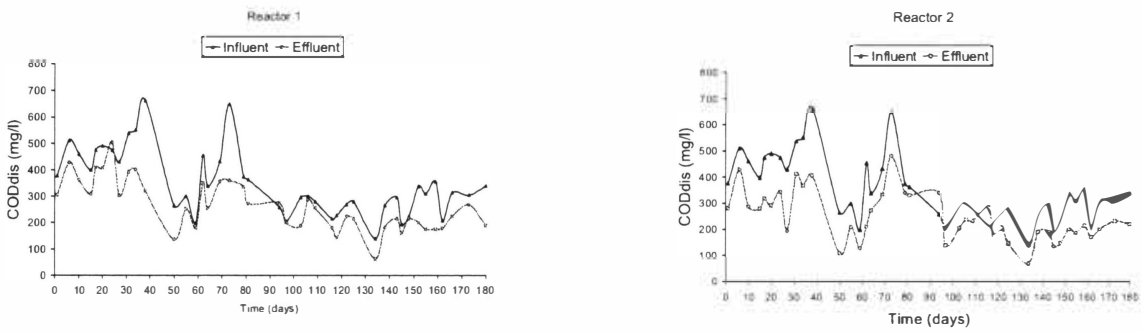

Figure 4. COD dis influent and effluent concentrations for RI (left) and R2 (right). 
In this research $\mathrm{COD}_{\text {dis }}$ in the effluent represents about $75.7 \%$ and $70.8 \%$ from $\mathrm{COD}_{\text {tot }}$ for $\mathrm{R} 1$ and R2, respectively. Those results are in agreement with those reported by [4] of $50 \%$ $\mathrm{COD}_{\text {dis }}$ out of the final effluent $\mathrm{COD}_{\text {tot }}$ ofæa UASB reactor. [8] also reported about $50 \%$ of the $\mathrm{COD}_{\text {tot }}$ effluent from UASB reactor was as $\mathrm{COD}_{\mathrm{dis}}$. The average VFA concentrations in the effluent of both reactors were $80(37) \mathrm{mg} / \mathrm{l}$ and 69 (38) $\mathrm{mg} / 1$ with average removal efficiency of negative removal and $2 \%(82)$ for $\mathrm{R} 1$ and $\mathrm{R} 2$, respectively. The concentrations of the VFA represent about $30 \%$ and $27.8 \%$ from the $\mathrm{COD}_{\text {dis }}$ so most of the $\mathrm{COD}_{\text {dis }}$ was in a non-acidified form in both reactors. Wang (1994) found about $46 \%$ of the effluent $\mathrm{COD}_{\text {tot }}$ after anaerobic sewage treatment could be attributing to non-acidified $\mathrm{COD}_{\text {dis }}$ as proposed by Van der last and Lettinga (1992). This COD part is apparently anaerobically non biodegradable. The VFA concentration in the effluent was affiected by temperature and the methanogenic conditions where the production of the VFA decreased during the winter period comparing to the results obtained during the hot period. The negative and low removal efficiency represents an increase in the VFA concentration which is mainly as a result of the predominant acidification process and apparently low methanogenic activities in the two reactors. [1] reported that declining temperature resulted in reduced production of VFA accumulate at the reactors and a complete conversion of VFA in to $\mathrm{CH}_{4}$ was achieved during 3 to 4 month of second year of the UASB-septic tank operation, when the temperature increased to more than $15^{\circ} \mathrm{C}$.

\subsection{Biodegradability of effluent}

The anaerobic biodegradability of the COD in the reactors effluents were $47.64 \%$ and $41.7 \%$ of $\mathrm{R} 1$ and R2 respectively after incubation period of 120 days at $30^{\circ} \mathrm{C}$ for the two tests conducted at day 204 and 250 from the start up of the UASB septic tank reactors.

\subsection{Hydrolysis, Acidification and Methanogensis}

The average values of the hydrolysis, acidification and Methanogenesis over the whole research period are summarized in Table 4.

Table 4. The calculated average values for Hydrolysis (H), Acidification (A) and Methanogenesis $(M)$ in both reactors ( $R 1$ and $R 2)$ for each month and over all average during total research period of six months. Standard deviations are presented in brackets

\begin{tabular}{lcccccc}
\hline \multicolumn{1}{c}{ Months } & \multicolumn{3}{c}{ Reactor 1 } & \multicolumn{3}{c}{ Reactor 2 } \\
& $\mathrm{H} \%$ & $\mathrm{~A} \%$ & $\mathrm{M} \%$ & $\mathrm{H} \%$ & $\mathrm{~A} \%$ & $\mathrm{M} \%$ \\
October, 2004 & 32.51 & 28.89 & 26.33 & 16.79 & 20.86 & 23.00 \\
November, 2004 & 21.65 & 22.09 & 26.97 & 10.93 & 9.32 & 22.47 \\
December, 2004 & 12.00 & 20.26 & 18.87 & 13.26 & 21.13 & 19.06 \\
January, 2005 & 28.58 & 25.91 & 24.09 & 28.29 & 23.69 & 21.80 \\
February, 2005 & 31.18 & 32.33 & 28.71 & 21.41 & 28.45 & 26.52 \\
March, 2005 & 27.19 & 31.01 & 29.87 & 23.39 & 26.34 & 27.07 \\
Average & $26(15)$ & $27(9)$ & $26(6.9)$ & $19(14)$ & $22(10.8)$ & $23(5.5)$ \\
\hline
\end{tabular}


Methanogenesis was apparently the rate limiting step for the overall conversion of organic matter to methane in both reactors as the effluent soluble and VFA COD remained relatively high. On the other hand, unexpectedly all of the anaerobic process rates (Hydrolysis, Acidogenesis and Methanogensis) in R1 were significantly $(\mathrm{p}<0.05)$ higher than those in R2 with longer HRT (see "Figure 5"). This is probably due to extra biogas production as a result of conversion of the accumulated biodegradable solids in the sludge bed of R 1 during the first half year of operation. Methanogensis might have increased because the amount of sludge in $\mathrm{R} 1$ was larger than R2 as will be shown later, thus more methane gas was evolved
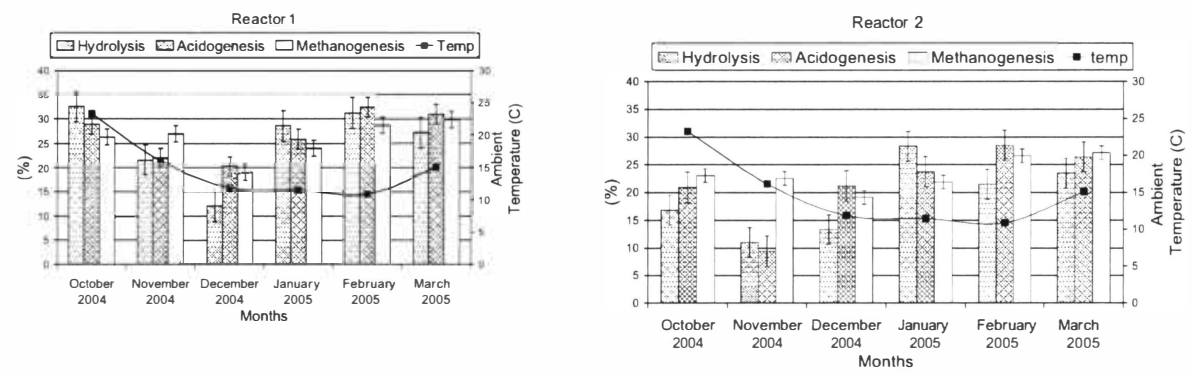

Figure 5. Percentage of hydrolysis, acidification and methanogenesis of domestic sewage treatment in UASB-Septic tanks R1 (left) and R2 (right).

\subsection{COD mass balance}

Some researchers have provided information about their systems that could lead to formulation of COD balance [1, 8-9]. The monthly COD mass balances over the two UASBseptic tank reactors during the period of the research are presented in Figure 6. 

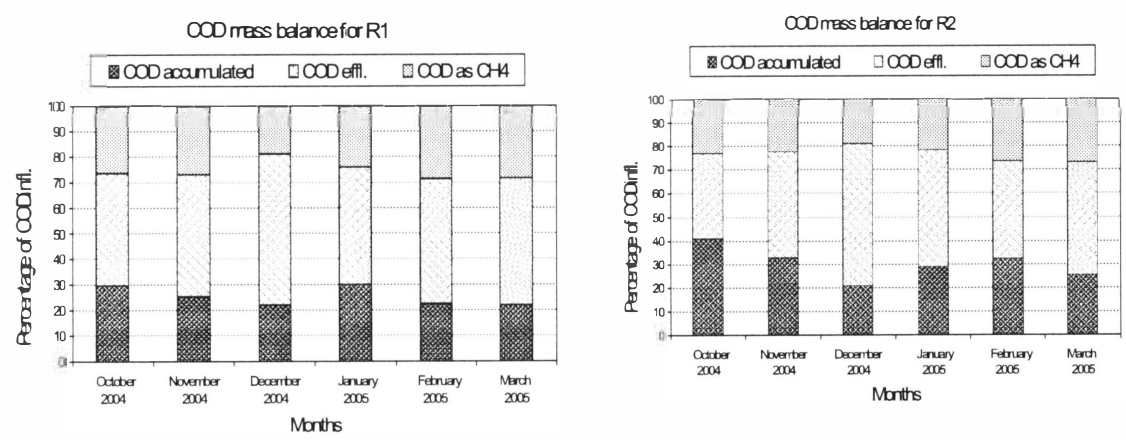

Figure 6. Monthly COD mass balance of RI (left) and R2 (Right) over the total test period as a percentage of aveeage influent $C O D_{t o l}$ and divided over $C O D$ accumulated, $C O D$ effluent and $\mathrm{CH}_{4}$ as $\mathrm{COD}$

Through analyzing Figure 6 for both R1 and R2 one can see that in the second month of monitoring and analysis (November), which took place when winter started, the accumulated COD started to decrease and washed out with the effluent COD without any change in the amount of methane production. In December when temperature started to decrease gradually, a reduction in the amount of COD accumulated and methane production was observed and so an increase in the amount of the effluent COD was observed. This observation during that month could be also proved by the lowest monthly COD removal efficiency during the period of the experiment about $41 \%$ and $40 \%$ for R1 and R2 respectively. Later on in January the removal efficiency of COD increased accompanied with an increase in the methane production and the amount of COD accumulated. Moreover, later in February and March (the fifth and the sixth month of the analysis period) the amount of methane production stayed approximately constant while the accumulated COD started to decrease with an increase again in the COD washed out with the effluent. During the six month of the research the COD mass balance could be represented about $25.25 \%$ and $30 \%$ of the COD accumulated in the reactor $\mathrm{R} 1$ and $\mathrm{R} 2$ respectively, and about $25.6 \%$ and $23.32 \%$ from the total COD entered the reactors $\mathrm{R} 1$ and $\mathrm{R} 2$ respectively converted to methane. The proportion of COD accumulated and found in R2 which is relatively higher than R1 justified the slightly better removal efficiency achieved in R2.

\subsection{TSS and VSS removal efficiency}

Both reactors performed equally good as the achieved TSS removal efficiencies were $74 \%$ (10) and $78 \%$ (11) by R1 and R2 respectively but with no statistical significant differences $(\rho>0.05)$ between the two reactors. The results reported for TSS in this research are better than the results reported in literature review for conventional UASB reactors that have treated domestic wastewater. The removal efficiencies averages for VSS for this research were $74 \%$ (10) and 78\% (12) for R1 and R2, respectively. However, R2 is significantly better than R1 with respect to VSS removal efficiency $(\rho<0.05)$. The VSS and TSS concentrations and removal efficiencies for R 1 and $\mathrm{R} 2$ were stable regarding to the TSS concentrations measured at the effluent throughout the period of the research. The achieved TSS and VSS removal 
efficiencies are rather good because the reactors were operated during the cold period of the year. [9] pointed out that the decrease in temperature would be accompanied with direct increase of the wastewater viscosity and so increase the hydraulic shearing force on solid particles. Accordingly the solids particles will move out the reactor which directly reduces the removal efficiency of both reactors. The average VSS/TSS ratio for both of the reactor R 1 and $\mathrm{R} 2$ were $0.84(0.06)$ and $0.81(0.04)$ respectively, which is closed to the results reported by (Al-Shayah, 2005).

\section{$3.7\left(\mathrm{NH}_{4}^{+}\right)$and $\left(\mathrm{Nk}_{\mathrm{j}}-\mathrm{N}\right)$ removal}

The removal of the $\mathrm{NH}_{4}{ }^{+}$was very low for both of the reactors where the average $\left(\mathrm{NH}_{4}{ }^{+}-\mathrm{N}\right)$ concentration for the UASB reactors Rl was 35.61 (20.71) $\mathrm{mg} / \mathrm{l}$ with average removal efficiency $11.47 \%$ (20.66) and so for R2 35.99 (21.21) mg/l with average removal efficiency of $13.06 \%$ (22.6). However, the difference in removal efficiency of $\left(\mathrm{NH}_{4}{ }^{+}-\mathrm{N}\right)$ were not statistically significant $(\rho>0.05)$. That also holds true for the $\mathrm{Nkj}-\mathrm{N}$ as $\mathrm{Nkj}-\mathrm{N}$ was partially removed in the USAB reactors due to particulate $\mathrm{N}$ removal (Table 3 ). The average removal efficiencies of $\mathrm{Nkj}-\mathrm{N}$ were $17 \%$ (7) and $15 \%$ (8.3) for R1 and R2, respectively. Moreover, the difference in removal efficiency of $(\mathrm{Nkj}-\mathrm{N})$ were not statistically significant $(\rho>0.05)$.

\subsection{Total - P and Ortho phosphorous removal}

The results presented in Table 3 show that the difference in Total - $\mathrm{P}$ concentration between influent and effluent in the two reactors was negligible. The results show that the Ortho phosphate concentration had apparently increased in both reactors effluents due to mineralisation of organically bound $P$. This observation also was pointed out by [10].

As a conclusion of the results that obtained through nutrient removal, one can say that the UASB- septic tank reactors are not efficient for removing nutrient from wastewater and only a change in the chemical forms of nitrogen and phosphorus take place as reported by [1]. Therefore, a nutrient removal can only be achieved in separate post-treatment step after the UASB septic tank [10].

\subsection{Sulfate removal efficiency}

In this research the average concentration for sulfate $\mathrm{SO}_{4}{ }^{-2}$ in the effluent of $\mathrm{R} 1$ and $\mathrm{R} 2$ was $38.37(8.23) \mathrm{mg} / \mathrm{l}$ and $36.47(10.74) \mathrm{mg} / \mathrm{l}$, respectively. No significant difference were found of $\mathrm{SO}_{4}{ }^{-2}$ removal efficiency between both reactors $(\rho>0.05)$. The influent concentration as shown at Table 3 was about $94.67(23.76) \mathrm{mg} / \mathrm{l}$ and so the removal efficiency for removing $\mathrm{SO}_{4}{ }^{-2}$ for reactors $\mathrm{R} 1$ and $\mathrm{R} 2$ are $57.65 \%(8,48)$ and $61.45 \%(6.16)$, respectively. The effluent qualities for $\mathrm{R} 1$ and $\mathrm{R} 2$ for $\mathrm{SO}_{4}{ }^{-2}$ were stable throughout the research period and it seemed to be not affected by the fluctuation in influent concentration.

\section{$3.11 \mathrm{pH}$ in the UASB- septic tank reactors}

In this research the $\mathrm{pH}$ mean value for the raw sewage Influent was $7.6(0.28)$ and $7.44(0.13)$ and $7.47(0.16)$ for the effluent of $\mathrm{R} 1$ and $\mathrm{R} 2$, respectively. The slightly lower $\mathrm{pH}$ values which was observed in the UASB effluent is expected in the anaerobic treatment where the buffering capacity in the raw domestic wastewater is enough to neutralize the production of volatile acids and carbon dioxide, which dissolved at the operating pressure [11]. During the whole of the experiment was no observation for $\mathrm{pH}$ value out of the normal and optimum range where for $\mathrm{R} 1$ the $\mathrm{pH}$ ranged from $\mathrm{pH}$ (7.14-7.68) and for $\mathrm{R} 2 \mathrm{pH}$ ranged from (7.1-7.79). 


\subsection{General discussion}

Form the average influent concentration of $\mathrm{COD}_{\text {tot }}(1045 \mathrm{mg} / \mathrm{l})$ during one year which was obtained by this research and the research don by Al-Shayah (2005) one can calculate the number capita equivalent to the $\mathrm{COD}_{\text {tot }}$ entered each reactor which is 3 capita and 2 capita for R1 and R2, respectively see Table 4.7. About 1892.5 l/c.year and 1321.85 l/c.year of $\mathrm{CH}_{4}$ in gaseous form were produced from R1 and R2, respectively as measured from the gas meter see Table 4.7. Moreover, the annual specific sludge production for each capita was $2.1 \mathrm{~kg}$ $\mathrm{TSS} / \mathrm{c}$.year and $2.7 \mathrm{~kg}$ TSS/c.year for R1 and R2, respectively see Table 5.

The accumulated COD in the sludge after 1 year per person in the reactors equal $2.29 \mathrm{~kg}$ $\mathrm{COD} / \mathrm{c}$.year and $1.86 \mathrm{~kg} \mathrm{COD} / \mathrm{c}$.year in $\mathrm{R} 1$ and $\mathrm{R} 2$, respectively see Table 4.7 . These values were reasonable related to (Jewell, 1994) who reported that for each $100 \mathrm{~kg}$ COD soluble treated there will be $5 \mathrm{~kg}$ COD converted to sludge as mentioned at Figure 2.1. Theoretically and regarding to [12], the amount of COD that present at the sludge equals $5 \%$ of the soluble COD. Regarding to this research the percentage was taken related to the total COD, relatively it is less than the results reached by [12] it was $4.5 \%$ and $4.8 \%$ from the total COD for R 1 and $\mathrm{R} 2$, respectively. In general the design criteria of community on site UASB-septic in Palestine are presented in Table 5. At Table 6 the OLR for R 1 with HRT of 2 days was $0.45(0.12)$ and for R2 with HRT of 4 days was $0.23(0.06)$. 
Table 5. General specification and results that Reached after one year of Full monitoring and operation

\begin{tabular}{|c|c|c|}
\hline Parameters & $\mathrm{R} 1$ & $\mathrm{R} 2$ \\
\hline${ }^{*}$ Average $\mathrm{COD}_{\text {tot }}$ during one year & $418 \mathrm{~g} / \mathrm{d}$ & $209 \mathrm{~g} / \mathrm{d}$ \\
\hline${ }^{* \star}$ Equivalent capita & 2.34 capitar 3 capita & 1.17 capita $\simeq 2$ \\
\hline $\begin{array}{c}\text { Gas produced from reactors in } 1 \text { year per } \\
\text { person. }\end{array}$ & $1892.5 \mathrm{l} / \mathrm{c} \mathrm{yr}$ & 1321.85 l/c.yr \\
\hline Height of the sludge at reactors & $0.5 \mathrm{~m}$ & $0.4 \mathrm{~m}$ \\
\hline Volume of the sludge & $0.16 \mathrm{~m}^{3}$ & $0.128 \mathrm{~m}^{3}$ \\
\hline${ }^{\star \star \star}$ Available Sludge at reactors & $7.01 \mathrm{~kg} \mathrm{TSS}$ & $4.23 \mathrm{~kg}$ TSS \\
\hline${ }^{\star \star *}$ Accumulated sludge during 1 year & $4.94 \mathrm{~kg}$ TSS & $3.23 \mathrm{~kg}$ TSS \\
\hline $\begin{array}{c}{ }^{* * *} \text { Annual Specific sludge produces per } \\
\text { person. }\end{array}$ & $2.1 \mathrm{~kg} \mathrm{TSS} / \mathrm{c} . \mathrm{yr}$ & $2.7 \mathrm{~kg} \mathrm{TSS} / \mathrm{c} . \mathrm{yr}$ \\
\hline Average Sludge COD during one year. & $43.32 \mathrm{~g} \mathrm{COD} / 1$ & $29.23 \mathrm{~g} \mathrm{COD} / 1$ \\
\hline $\begin{array}{l}{ }^{+} \text {The amount of sludge available at the } \\
\text { Reactors as COD after } 1 \text { year per person. }\end{array}$ & $2.29 \mathrm{~kg} \mathrm{COD} / \mathrm{c} . \mathrm{yr}$ & $1.86 \mathrm{~kg} \mathrm{COD} / \mathrm{c} . \mathrm{yr}$ \\
\hline
\end{tabular}

* The calculation done after one year of continuous operation and monitoring during this research and the research done by Al-Shayah, 2005, where the average COD of influent for one year in AWWT $=[($ this research/Number of samples) + (Al-Shayah 2005/number of samples)]/total number of samples at one year $\rightarrow$ A verage total COD inter to the reactor each day $=$ flow rate $(\mathrm{L} \backslash \mathrm{d}) *$ Average COD $(\mathrm{mg} \backslash \mathrm{L})$

${ }^{* *}$ The specific production of $\mathrm{COD}_{\text {tot }}(\mathrm{g} / \mathrm{c} . \mathrm{d})$ range from (155-202) with average value of $179 \mathrm{~g} / \mathrm{c}$.d as reported by [9], $\rightarrow$ Equivalent population for the Treatment plant reactors in Capita $=$ Average total COD inter to the reactor each day (g\d) / Specific COD Production (g\c.d))

"Total Mass of sludge at the reactor $\mathrm{kg}$ TSS/year $=$ [The average sludge TSS of in the reactor $\left({\left.\mathrm{g} \backslash \mathrm{m}^{3}\right)}^{*}\right.$ volume of sludge at the reactor $\left.\left(\mathrm{m}^{3}\right)\right] \rightarrow$ Accumulated mass of sludge at the reactor $(\mathrm{kg}$ TSS$/ \mathrm{yr})=[$ (Total Mass of sludge at the reactor $\mathrm{kg} \mathrm{TSS} / \mathrm{yr}$ ) - (Mass of sludge added at start up)], where at start up the amount of sludge added to the reactor are $160 \mathrm{~L}$ at $\mathrm{R} 1$ and $80 \mathrm{~L}$ in $\mathrm{R} 2$. With TSS $=13.78(\mathrm{~g} \backslash \mathrm{I})$ so mass of the start up sludge added to $\mathrm{R} 1=1601 \times 13.78(\mathrm{~g} \backslash \mathrm{l})=2.2 \mathrm{~kg}$ TSS and $801 \times 13.78(\mathrm{~g} \backslash \mathrm{l})=1.1 \mathrm{~kg}$ TSS for R2. (Al-Shayah, 2005), The specific sludge produced per person in one yeare $=$ [Accumulated mass of sludge at the reactor $(\mathrm{kg}$ TSS/year) / Equivalent Population (Capita) $] \mathrm{e}^{+}$COD at Sludge $(\mathrm{kg}$ COD $\backslash \mathrm{c} . \mathrm{yr})=[$ (Average COD concentration of sludge (g/l) * volume of sludgee)/ capita]

\section{CONCLUSIONS}

- The here presented UASB-septic tank reactor is a very efficient technology for onsite sewage treatment in Palestine. It achieved the following main removal efficiencies:

- The reactor can be adequately designed at either 2 or 4 days HRT, but preference might be given to 4 days HRT when sludge production is of concern 
Removal efficiency (\%)

\begin{tabular}{cccccc}
\hline HRT & $\begin{array}{c}\text { OLR } \\
\left(\mathrm{kgCOD} / \mathrm{m}^{3} . \mathrm{d}\right)\end{array}$ & $\mathrm{COD}_{\text {tot }}$ & $\mathrm{COD}_{\mathrm{ss}}$ & $\mathrm{COD}_{\mathrm{col}}$ & $\mathrm{COD}_{\mathrm{dis}}$ \\
2 & $0.45(0.12)$ & $51(9)$ & $83(10)$ & $20(32)$ & $24(15)$ \\
4 & $0.23(0.06)$ & $54(11)$ & $87(8)$ & $10(37)$ & $28(18)$ \\
\hline
\end{tabular}

\section{REFERENCES}

[1] Bogte, J. J., Breure A. M., van Andel J. G., and Lettinga G., 1993. Anaerobic treatment of domestic wastewater in small scale UASB reactors. Water Sci. Technol.e 27(9), 75-82.

[2] Lettinga, G., Man, A. W. A. de., Last, A. R. M. van der, Wiegant, W., Knippenberg, K., Frijns, J., Buuren, J. C. L. van, 1993. Anaerobic treatment of domestic sewage and wastewater. Water. Sci. Technol.e 27(9), 67-73.

[3] Mahmoud, N., Amarneh, M. N., Al-Sa'ed, R., Zeeman, G., Gijzen, H., Lettinga, G., 2003. Sewage characteristics as a tool for the application of anaerobic treatment in Palestine. Environmental Pollution, 126, 115-122.

[4] Halalsheh, M. M., 2002. Anaerobic pre-treatment of strong sewage A proper solution for Jordan. Ph.D. thesis, Wageningen University, Wagcningen, The Netherlands.

[5]Zeeman, G., Lettinga, G., 1999. The role of anaerobic digestion in closing the water and nutrient cycle at community level. Water Sci Technol., 39(5), 187-194

[6] APHA (1995) Standard methods for the examination of water and wastewater. 18th

[7] Elmitwalli, T. A., Sklyar, V., Zeeman, G., Lettinga G., 2002. Low temperature pretreatment of domestic sewage in an anaerobic hybrid or an anaerobic filter reactor Biores. Technol., 82, 233-239.

[8] Seghezzo, L., 2004. Anaerobic treatment of domestic wastewater in subtropical regions. Ph.D. thesis, Wageningen University" Wageningen, The Netherlands.

[9] Mahmoud, N., 2002. Anaerobic pre-treatment of sewage under low temperature $\left(15^{\circ} \mathrm{C}\right)$ conditions in an integrated UASB-digester system. Ph.D. thesis, Wageningen University, Wageningen, The Netherlands.

[10] Haandel, AC. Van, Lettinga, G., 1994. Anaerobic Sewage Treatment. A Practical Guide for Regions with a Hot Climate. John Wiley and Sons, New York.

[11] Drost, R. L., 1997. Theory and practice of water and wastewater treatment. John Wiley \& Sons lnc, Canada.

[12] Jewell, W. J., 1994. Resorce Recovery Wastewater treatment. American Sci. Vol. 82. pp 366-375. 